North shore of Lake Winnipeg, the section exposed being a natural one, and is as follows:-

1. Loam, 3ft.

2. Hard rock (Limestone?) $10 \mathrm{ft}$.

3. Pyritiferous sand, silvery to the eye when fresh, $4 \mathrm{ft}$. (exposed).

The pyrites forms so large a portion of the sand that it might be worth while to work the deposit; mere washing would probably separate the ore readily from its matrix. The composition of the pyrites is said to be $\mathrm{Fe} 46 \cdot 4 \mathrm{~S} 53 \cdot 6$.

With regard to the origin of the pyrites, can it have been formed in situ in the sand, or is it as well as the sand the product of the disintegration of an older rock? I can find no account of any similar deposit elsewhere; the nearest approach to such a bed in character seems to be met with in beds containing dininutive spherical nodules of iron ore in Manitoba, but these are not pyrites; they are chalybite and much larger; and it is said in the report of the Survey of the 49 th Parallel, that a thin film of pyrites in the Lignite deposits near Porcupine Creek was the first appearance of that mineral in connexion with those deposits.

J. Magens Melzo.

The Rectory, Brampton, S. Thomas, Chesterfield, June 28, 1879.

\title{
GLACIATION OF THE WEST YORKSHIRE DALES.
}

Sin,-Will Mr. J. W. Davis kindly tell us what evidence he has to show that either the Scotch or Lake Country ice, after traversing the valley of the Eden, passed down Wensleydale, Arkendale, and Swaledale, as stated by him in your last Number, p. 315? I think the statement must be new to most of your readers, unless they have seen a somewhat similar one in Davis and Lee's West Yorkshire. Surely if the ice took this course, these dales should abound in erratics. Yet so far as $I$ know there are no foreign bonlders in Wensleydale-only local ones. There are no erraties in Arkendale and none in Swaledale, except in the lowest part of the dale near Richmond, where it can be shown clearly that they came over the watershed from the north, out of Teesdale. Mr. Davis must have entirely misunderstood Mr. Goodchild's paper on this matter. It may look at first sight to an outsider as if the ice ought to have behaved differently, especially when it did not pass from the Eden Valley over the low watershed into Wensleydale. "But facts are chiels that winna ding." Perhaps it is not generally known that the Lake Country ice in passing over Stainmoor did not take the direction of the lowest pass, 1378 feet above the sea, and so cross where the Stainmoor railway goes over into the valley of the Greta, but it passed over higher ground further north into Deepdale, Balderdale, and Lunedale, and erratics have been found by Mr. Goodchild and myself at various heights up to 1800 feet on the watershed between the Eden and the Tees.

BERWICK-ON-TWEED,

W. GUNN, July 12, 1879.

Geol. Strv. of Exg. and Wales. 